\title{
Sustainability - a key to Australian finance directors improving their organisation's CSR culture
}

\begin{abstract}
:
Sustainability, as one of six (economic, ethical, social, stakeholder, sustainability, and discretionary) dimensions of corporate social responsibility (CSR) is frequently espoused in large finance organisations' corporate reports. In this case study on finance board directors conducted in the lead-up to the Royal Commission into Misconduct in the Banking, Superannuation and Financial Services Industry (hereafter Commission), sustainability assumptions were not found to be a day-to-day consideration for the majority of directors. Directors' primary assumptions, their values-in-use, were finance first, followed by risk and defence. Finance, in terms of short-term profitability, was considered before all espoused values such as customer centricity, integrity, trustworthiness, and professionalism. Within the study there were a small number of directors who did prioritise sustainability, which they closely integrated with the economic (finance). The additional prioritisation of sustainability led to better integration of the other CSR dimensions and a reduced difference between what is said (espoused) and done. While other CSR and finance studies have focused on "how much", this study provides unique insights into the "why" of the finance industry's values-inuse preceding the 2018 to 2019 Commission which exposed some of the "what" and "when" of director behaviour.
\end{abstract}

Key words: sustainability, organisational culture, corporate social responsibility, directors, finance, and subculture

\section{Introduction}

Board directors of large Australian finance organisations, be they banks, insurance, superannuation, or wealth management entities, are the custodians of their culture (Australian Securities \& Investment Comission., 2013). The assumptions of these directors impacts 450,000 of their subordinates and millions of customers (Australian Government Department of Treasury, 2016). Over the past two decades directors of finance organisations have 
increased their espousing of customer centricity in corporate reports; however, cultural issues remain (Australian Council on Superannuation Investors, 2017; Higgins, Milne, \& Van Gramberg, 2015). Government and regulatory inquiries into the industry have consistently found problematic cultural issues, such as unfair treatment of consumers and a lack of accountability (Australian Government Department of Treasury, 1997; Campbell, 1981; Murray, 2014). The Commission found the industry was "dishonest and greedy" (Hayne, 2018, p. 73). Dishonest and greedy cultures foster misconduct: when allied to large finance organisations this has a significant impact on individual customers, their families, and broader society. Evidence of this impact came to light in Commission hearings as televised customer stories detailed how farmers were driven off their land, people with cognitive disability targeted for products not-fit-for-purpose, and loans issued to vulnerable people who could not afford repayments (Hayne, 2018, 2019b).

Culture within the finance industry has been studied less than other industries, such as sport, media, arts, and architecture (Li, Griffith, Yue, \& Zho, 2013). This study moves beyond studying finance from corporate reports because it features interviews from directors in the lead-up to the Commission. Director's quotes speak to their lived experience, disclosing how the industry was being driven by a "profit right now philosophy" [PQ: director pseudonym]. These participants also spoke of frustration at CSR advocates, because "your morality is fine, just don't ask me to pay for it" [TV]. There was also frustration at the conduct of peers within industry some referring to them as "cowboys" [RS, PQ, LM] who need to be driven out of the industry. In one instance a director [PQ] stated, "I would kill him [cowboy: former colleague] if it were legal." The thematic insights from the director's voice, triangulated with their corporate reports, and observational checklists in this study contributes to "why" some of the cultural norms around CSR exist within the finance industry (Yin, 2018). 
To clarify the applied meaning of CSR, the six dimensions "economic, ethical, social, stakeholder, sustainability, and discretionary" provide a multi-dimensional view (Sarkar \& Searcy, 2016, p. 1432). Training and research within the finance discipline has traditionally approached issues from a one-dimensional economic reality (Morgan, 1988). Within this positivist paradigm, quantitative certainty is sought, rather than confidence from wider interpretive claims of human observation (Helms Mills \& Mills, 2017; Lichterman, 2017). Certainty is a challenge in CSR, particularly the sustainability dimension, because it is complex and not well understood (Pellegrini, Annunziata, Rizzi, \& Frey, 2019). Organisational culture (OC), incorporates complex, multiple realities, in addition to the economic reality (Bencherki, Basque, \& Rouleau, 2019; Sackmann \& Phillips, 2004); therefore, $\mathrm{OC}$ is utilised in this research. Academic literature looking into Australian finance culture from a systemwide perspective has been described as "sorely lacking," and presenting a "tremendous opportunity" (Ashkanasy, Humphrey, \& Huy, 2017, p. 181; Sheedy, Griffin, \& Barbour, 2017). OC has been underused within the finance industry (Ardalan, 2016). This overt focus on quantitative research and the lack of culture focus resulted in minimal fieldwork being conducted on large, complex finance organisations' subcultures, in particular the powerful director subculture (Jahdi \& Acikdilli, 2009; Sheedy \& Griffin, 2018). The problem here is that these issues remain underexplored, yet, the problems with culture remain.

Particularisations to do with director assumptions is said to be a black box, assumptions are unknown (Cummings \& Worley, 2015; Leblanc \& Schwartz, 2007). The absence of this knowledge is significant because director assumptions drive OC: it can either embed or circumvent CSR (Schein \& Schein, 2016). The significance of poor CSR assumptions driving finance organisations was seen during the 2008 Global Financial Crisis (GFC), which cost an estimated US\$20 trillion dollars (Biktimirov \& Cyr, 2013). Following 
the GFC, Australian finance organisations, run by directors, received numerous accolades for CSR and was regarded as "unquestionably strong" (ACCSR, 2016, 2015; World Economic Forum, 2012). Regulators and commentators have stated directors economic acumen contributed to an overconfidence in their ability to address non-finance areas (Laker, Broadbent, \& Samuel, 2018; Roddan, 2019).

Large finance organisations have continued to espouse their commitment to an integrated CSR approach, aligning their reported activity with United Nations (UN) protocols, the Global Reporting Initiative (GRI), and International Standards (ISO) (Commonwealth Bank, 2018; National Australia Bank, 2018). These integrated, virtuous depictions are mismatched to over 10,000 aggrieved customers who made submissions to the Commission (Hayne et al., 2019). Given the mismatch between directors' espoused values and external findings, this exploratory case study investigates, Why do finance directors' espoused values in corporate reports differ from their day-to-day assumptions of CSR?

To investigate this "why" question, an interpretive, qualitative approach is needed because the assumptions so far have been reliant on underlying justifications in economic rational thought. Qualitative quality is important given past research into finance found some organisations doing well (financially) were also doing good (CSR) based on positivist research. Later it was found some of these organisations were doing poorly from a CSR and cultural lens (Alvesson, Gabriel, \& Paulsen, 2017; Crane, 2000; Eihholtz, Kok, \& Quigley, 2010; Fleming \& Jones, 2013). To explore this further, a thematic content analysis of data used the six CSR dimensions and three levels of director subculture - artifacts, espoused values, and assumptions - as frames of reference (Baumgartner, 2014, 2009; Schein, 2016, 2010, 1992, 1985). The following literature review explores culture and CSR in more detail with a particular focus on finance directors' assumptions (values-in-use) which provides an indication of their organisation's lived reality of CSR. 


\section{Literature Review}

The theoretical underpinnings of this research draws on the second wave of organisational development (OD), in particular Schein and Schein's (2016) three levels of OC and Sarkar \& Searcy's (2016) six dimensions. CSR and OC will be discussed as they relate to directors of large Australian finance organisations. In this paper large organisations are defined as per the Australian Corporations Act (2001). They possess at least two of the following three attributes: generate over $\$ 25$ million in consolidated revenue per year, own at least $\$ 12.5$ million in consolidated gross assets, and employ more than 50 staff (Austlii.edu.au, 2016). Trust in the Australian finance industry is low: $21 \%$ believe banks have their best interests at heart (Endelman, 2018; Punt, 2018). Australian finance directors are the number one group least likely to show leadership for the greater good (Wilson, Pallant, \& Bednall, 2019). The Commission provided evidence of numerous large finance organisations lacking CSR consideration, which led to people losing their homes and their livelihoods, systemic money laundering, and dead people being charged fees for no service (Hayne, 2018). In sum, the Comission found there was a cultural problem within the industry; indeed, "culture" was referred to 282 times in the first volume of the final report (Hayne, 2019a). The best time to explore culture is when there is a problem (Schein \& Schein, 2016).

\section{Organisational culture and subculture}

In this study, the context is large organisations that encompass both homogenous macro culture and heterogeneous subcultures (Schein \& Schein, 2016). Here the three levels of organisational culture theory to explore director subculture are artifacts, espoused values and beliefs, and basic underlying assumptions (Figure 1). At level 1, artifacts are "visible and feelable structures and processes", such as organisational charts, building architecture, and clothing, which can be easily observed but are difficult to decipher (Schein \& Schein, 2016, p. 18). The single use of artifacts as indicators of culture, particularly for CSR or sustainable 
culture research, raises questions of efficacy due to its superficial nature (Alvesson, Gabriel, \& Paulsen, 2017; Russell \& McIntosh, 2011). At level 2, espoused beliefs and values refers to ideologies, goals, and rationalisations. Espoused values are easy to find in corporate reports and websites; they reflect what ought to be congruent with behaviour and artifacts (Schein \& Schein, 2016). Like artifacts, there are dangers with relying on espoused values because there is no chain of evidence to support what has been said is what has been done (Searle, 1969; Yin, 2018). Corporate reports provide espoused values that are of "status value only, no matter how strongly proponents may believe they are uttering the absolute truth" (Argyris \& Schon, 1978; Schein, 2010, p. 10). In short, relying on artifacts and espoused values is not trustworthy, particularly when investigating CSR dimensions such as sustainability, because they are not accurate indicators of the values-in-use (Argyris, 2010; Russell \& McIntosh, 2011). Level 3 assumptions are the ultimate drivers of an organisation's values-in-use.

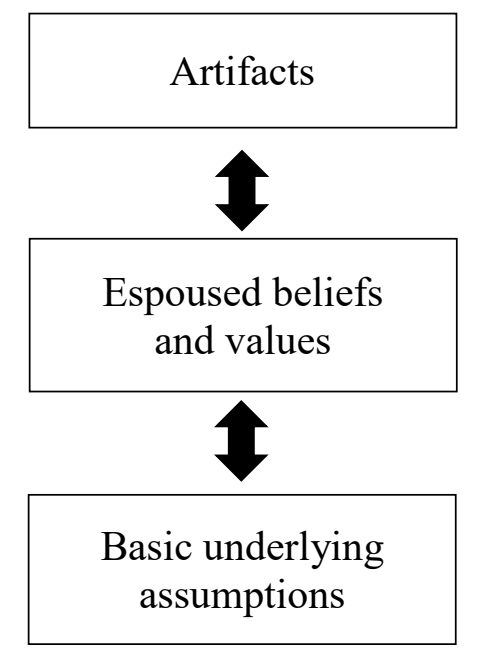

Level 1: visible organisational structures and processes; easy to see, hard to decipher

Level 2: ideals, goals, \& aspirations; espoused justifications are easy to find in corporate reports and websites but may not be congruent with behaviour and other artifacts

Level 3: unconscious, taken-for-granted beliefs and values, perceptions, thoughts, and feelings; difficult to find but ultimate source of values and action (values-in-use)

\section{Figure 1}

Levels of culture (Schein, 1985, 1990, 2010; Schein \& Schein, 2016)

Level 3 assumptions originate from espoused values expressed by either the founder or directors (Schein \& Schein, 2016). In established organisations directors take a risk when challenging an existing assumption because it could result in exclusion from the board, their 
subculture which provides a sense of belonging. Fear of challenging values-in-use within a subculture is real: it could lead to embarrassment, rejection, punishment, and excommunication from the subculture (Argyris, 2010). Not asking questions of management and not challenging existing assumptions were found to be significant director issues by the Commission (Hayne, 2019a). Presently, there is scant field research on finance director subculture detailing whether there is psychological safety on boards enabling "undiscussables" to be discussed (Edmondson, 1999; Schein \& Schein, 2016). The next paragraphs discuss subcultures in greater depth.

Directors, the dominant subculture of large organisations, are the focus of this case study because they are the catalyst for driving OC (Howard-Grenville, Bartels, \& Laheman, 2014). As sensegivers, directors "attempt to influence the sensemaking and meaning construction towards a preferred redefinition of [their] organisation's reality," (Gioa \& Chittipeddi, 1991, p.442), namely the reality of its values, growth, finance, and survival (Schein, 2016; Seto-Pamies, 2015). Director subculture has the ability to influence or even prevent CSR and sustainability embeddedness because staff are guided by them for sensemaking (Howard-Grenville, 2006; Kok, de Bakker, \& Groenewegen, 2017).

Within the director subculture role, survival of the organisation in the short-term and long-term is stated as a priority (Russell \& McIntosh, 2011). The Commission made reference to short-term assumptions being embedded within organisations through formalised systems such as remuneration structures (Hayne, 2019a). How and why these assumptions came to be normalised throughout the industry is not known (Sheedy \& Griffin, 2018). Changing elements of culture can be psychologically painful as it can destabilise an individual or subculture's cognitive interpersonal world (Argyris, 1990a; Schein \& Schein, 2016). To avoid cognitive destabilisation associated with change some subcultures become "too cosy", where forced fusion reinforces denial of differences to avoid conflict and anxiety 
(Cucari, Esposito De Falco, \& Orlando, 2018; Pope, 2019). Subcultures with high conformity levels avoid change, leaving issues unresolved (Oeij, Dhondt, Gaspersz, \& Vroome, 2016; Schein \& Schein, 2016). If change is proposed that challenges assumptions, defence mechanisms may arise as an individual or subculture's reality violates the preferred view of self or their subculture (Pope, 2019; Russell \& McIntosh, 2011); therefore, "habitual and unconscious strategies are used to deny, distort, or counteract sources of anxiety to help maintain an idealised self-image" (Oldham \& Kleiner, 1990, p. 1). In short, OC, in particular director subculture, has a significant impact on the values-in-use throughout an organisation; this includes their CSR assumptions.

\section{Corporate Social Responsibility (CSR)}

The definition and focus of CSR has gone through many iterations since its inception sixty years ago (Kolk, 2016; Stewart \& Gapp, 2014). For the past two decades, there has been greater emphasis on the sustainability dimension of CSR (Eweje, 2011; Jahdi \& Acikdilli, 2009; Sarkar \& Searcy, 2016). The most significant barrier to CSR embeddedness is directors (Jizi, 2017; Sugita \& Takahashi, 2015). In this paper the six CSR dimensions of "economic, ethical, social, stakeholder, sustainability, and discretionary" have been distilled from a study of 110 CSR definitions (Sarkar \& Searcy, 2016, p. 1432). These six dimensions are comprehensive and flexible enough to accommodate the financial context without the need to use CSR terminology, which can detract from authentic fieldwork dialogue (Baden \& Harwood, 2013). For example, the economic dimension encompasses profit maximisation, cost avoidance practices, shareholders, economic responsibility, strategy, and governance, which includes complying with regulations. When practitioners refer to reputation, transparent reporting, and integrity considerations, they are addressing the ethical dimension (Sarkar \& Searcy, 2016; Terjesen \& Sealy, 2016). Staffing issues and gender ratios are captured in the social dimension. Remuneration, service, and broader society fall under the 
stakeholder dimension. Environmental social governance (ESG), environmental value and protection, superannuation, and time orientation are to do with the sustainability dimension. Finally, volunteering and doing more than what is needed for compliance is captured in the discretionary dimension. When considering these dimensions, there is strong support for all CSR dimensions to be integrated, not stand-alone (Asif, Searcy, Zutshi, \& Fisscher, 2013; Porter \& Kramer, 2011; Vitolla, Rubino, \& Garzoni, 2017). If only one dimension is considered negative externalities abound.

Exploration of CSR, which incorporates the sustainable dimension, can vary depending on region. Within the North American context there is a strong focus on the business case for CSR where studies have found a link between financial performance and CSR activity (Barnett, 2016; Carroll \& Shabana, 2010; Kurucz, Colbert, \& Wheeler, 2008). European scholars also present a business case for CSR (Hahn, Preuss, Pinkse, \& Figge, 2014; Hockerts, 2015; Salzmann, Ionescu-somers, \& Steger, 2005), but add complexity, the multiple dimensions of CSR, need due consideration (Hahn, Figge, Pinkse, \& Preuss, 2018). A combination of European and North American studies have reviewed the need for shared and collective CSR value (Busch, Hamprecht, \& Waddock, 2018; Porter \& Kramer, 2011). Asian CSR research highlights the contextual issues of the region, such as government power, labour rates, education disparity, and more recently quantifying CSR reporting (Chapple \& Moon, 2007; Jain, Keneley, \& Thomson, 2015; Kim \& Moon, 2015). Within the Australian context, there has been a focus on governance, reporting, stakeholder engagement, and small-to-medium sized organisations (Beck, Frost, \& Jones, 2018; Lane \& Devin, 2018; Sheedy, 2016; Stewart \& Gapp, 2014). Across all regions, including Australia, there is an increasing focus on the role of board diversity and corporate governance (Furlotti, Mazza, Tibiletti, \& Triani, 2018; Galbreath, 2011; Manning, Braam, \& Reimsbach, 2019; SetóPamies, 2015; Uribe-Bohorquez, Martínez-Ferrero, \& García-Sánchez, 2018). As yet, there 
has not been field research into board directors CSR subculture in Australia, or other regions. The next section explores finance directors.

\section{Finance directors}

All board directors, whether executive or non-executive, are to act objectively in good faith and in the best interest of their organisation under the Corporations Act (2001) s180. Australians trust in large institutions, in particular large finance organisations, is at an alltime low (Endelman, 2018; Wilson et al., 2019). Commission findings detailed how customers lost large portions of their life savings and were negatively impacted psychologically, socially, and physically because of their economic loss (Hayne, 2019a, 2019b). These outcomes, stemming from misconduct within finance organisations, are indicative of a culture of financialisation where there is an overarching orientation towards generating shareholder value through increased profits in the short-term (Fligstein, 1990; Stout, 2012). Financialisation can lead to an "obsessive search for financial returns" that "dehumanises" behaviour (Palpacuer, Seignour, \& Vercher, 2011, p. 578) and compromises the ethical culture of an organisation (Chabrak, Craig, \& Daidj, 2016). As discussed earlier, directors are the custodians of culture, they set the tone from the top, it is their duty to be aware of the lived reality of internal culture as well the broader societal culture.

Socially responsible investors continue to advocate for OC where CSR is prioritised, in particular the sustainability dimension (Schreck \& Raithel, 2018; Ulysses, 2017; Wiengarten, Lo, \& Lam, 2017). Quantitative research has not revealed why finance directors fail to integrate CSR into their culture. CSR is a value driver that lowers risk (Ali, Danish, \& Asrar-ul-Haq, 2019; Buertey, Sun, Lee, \& Hwang; Busch \& Friede, 2018). Finance organisations with a strong sustainability performance are less risky and "suffer less during a time of crisis" (Ducassy, 2013, p. 164). Managing risk, compliance and crisis are expected of 
finance directors in Australia (Australian Prudential Regulation Authority, 2016). This literature review has found evidence of espoused values being decoupled from assumptions; yet, there is minimal qualitative evidence on why director assumptions differ from their espoused values. The methodology used to explore this problem further is presented in the next section.

\section{Methodology}

The methodology used to address the research question on directors' CSR assumptions and why this differs from their espoused values is an interpretive, qualitative case study (Yin, 2018), see Figure 2. Interpretive case study is an effective and appropriate platform to explore directors assumptions, their values-inuse, and how these contrast or corroborate with their stated CSR espoused values (Sugita \& Takahashi, 2015; Van Manen, 1997). Another justification for the interpretive paradigm is that research has to do with "meaningful social action, socially constructed meaning, and value relativism” (Burrell \& Morgan, 1979; Neuman, 2014, p. 103). Avoidance of superficiality is another factor in the methodological selection; this quality research design aims to avert participants defaulting to prepared cultural scripts or misinterpreting questions (Kvale, 2007; K. Tracy, 1995). The semi-structured interview design provided an opportunity to ask probing questions of the 11 participants from 10 commercial and not-for-profit (NfP) organisations, capturing directors' values-in-use when overseeing a large finance organisation (Angen, 2000; Yin, 2018).

Interview questions were developed considering the literature review which incorporates the CSR and cultural underpinnings. One example of a question to elicit their lived experience and garner a requisite variety of responses was, "What are your key day-to-day tasks as a director?" (Weick, 1987). Such questions were 
coupled with subtle probing, asking how and why in a "friendly and nonthreatening" way (Dick, 1990; Yin, 2014, p. 110). Accessing directors is known to be difficult due to internal and external organisational commitments (Leblanc \& Schwartz, 2007). To address this challenge, snowballing, also known as a referral technique, was used to garner a participant pool (Migliore \& DeClouette, 2011). Contact with the first director was made through the researchers' industry connections, this director then referred the researchers onto another director, and another, until saturation of exploratory data was achieved. Initial coding of data occurred following each interview. The thick and rich data generated offered approximately 100 codes from each interview. At the time of the eighth interview, a number of common concepts and themes were corroborating between the participant responses and it appeared saturation was reached. To ensure key exploratory themes were indeed captured, three more interviews were conducted, which aligned with the earlier interviews (Ness, 2015). Six of the interviews took place in the directors' Brisbane workplaces and five interviews were conducted over the phone because the directors were based in Sydney or Melbourne. The average duration of the interviews was 52 minutes, and all were recorded using electronic audio devices before being manually transcribed. 


\section{Figure 2. Options and justification of methodology}

Adapted from Stewart and Gapp (2017)

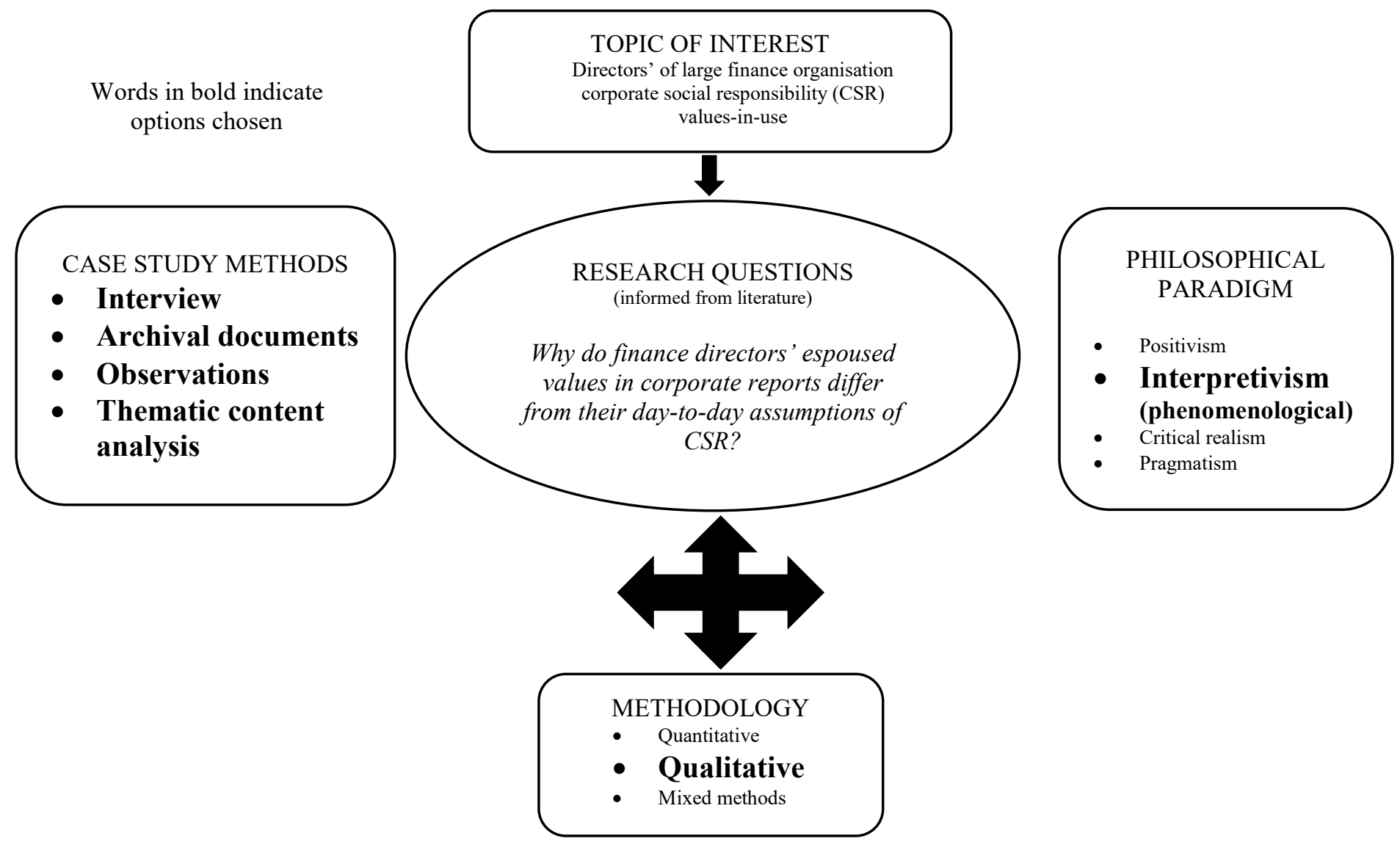

As indicated in Figure 2, archival documents from directors' corporate reports were utilised to capture their espoused values. Observation methods were used to capture artifacts, and interviews captured assumptions. During triangulation of the three data sets (interview, reports, observation) convergent findings either corroborated or revealed "inconsistent or contradictory evidence" (Angen, 2000, p. 384). This triangulation occurred within and between data sets, which often found corroboration within data sets, but contradiction between data sets. Analysis of the data included theoretical triangulation because all data was reviewed in light of CSR and OC theory (Yin, 2018). Consistency of thematic findings gave confidence to the researchers that the data collected was trustworthy. Triangulation, as well as 
sincerity through transparency and topic worthiness contributed the qualitative quality approach (Tracy, 2010; Yin, 2018). Table 1 details the thematic content analysis process over four phases: “coding, categorising, conceptualising, and themes" (Saldaña, 2015, p. 14). At each phase of analysis, the three levels of culture and six CSR dimensions served as the external ontological referent, or test, to guide the formation of themes (Johnson \& Duberley, 2000). Other referents could have been used such as corporate governance, institutional theory, and stakeholder theory, but these theories would not have answered the specifics of the research question (Ortiz-de-Mandojana, Aguilera-Caracuel, \& Morales-Raya, 2016). Reflexivity that involved re-reading and reflecting on taken-for-granted assumptions such as "we're not mining" as well as what was not being said in most instances, such as "sustainability" was ongoing which led to recursive action with the four phases; this activity also added to the rigorous approach (Cunliffe, 2003). Similarly, there was ongoing self-reflexivity as the researchers discussed their own predispositions, challenging personal bias and assumptions (Angen, 2000). 
Table 1. Thematic content analysis

Adapted from Braun and Clarke (2006), Clarke and Braun (2018), Cunliffe (2003), Kolko (2010), Saldaña (2015), and Sandberg (2005)

\begin{tabular}{|l|l|}
\hline Phase \& description & Action \\
Coding phase: & $\begin{array}{l}\text { Data immersion: listening and manually transcribing interviews, reviewing } \\
\text { observational checklist, and viewing archival documents from reports and } \\
\text { websites. Observing participants, which included recognising physical } \\
\text { reactions, attire, and omissions, as well as work environment. Commenced } \\
\text { coding, discussed interpretations, prioritised data, and checked for researcher } \\
\text { bias }\end{array}$ \\
\hline $\begin{array}{l}\text { Second phase: } \\
\text { Categorising }\end{array}$ & $\begin{array}{l}\text { Reviewed top-down (CSR and OC theory) and bottom-up (real-life } \\
\text { observation) codes, forging new connections. Identified and judged relevance } \\
\text { of commonalities and differences within and between data using CSR } \\
\text { dimensions and cultural lens. Noted if language is positive, negative, or } \\
\text { neutral. Used Derwent pencils and highlighters to identify and note codes line- } \\
\text { by-line, making analytical notes around keyness and intensity of multiple } \\
\text { codes to draw categories within the codes. Cross-checked and observed } \\
\text { similarities, irregularities, and contradictions }\end{array}$ \\
\hline $\begin{array}{l}\text { Third phase: } \\
\text { Ronceptualising }\end{array}$ & $\begin{array}{l}\text { Reviewed codes and categories (again) of the entire data in light of the } \\
\text { research question to identify central organising concepts (underlying } \\
\text { assumptions). Reflexively re-read transcripts from a normative perspective to } \\
\text { further distil assumptions from espoused values and artifacts. Reviewed } \\
\text { analytical memos developed during triangulation: finding corroboration, } \\
\text { irregularity, and contradictions. Use of Word, Excel, and pen-paper for } \\
\text { analytical note taking. Discussed keyness of concepts and reviewed self- } \\
\text { reflexive notes }\end{array}$ \\
\hline $\begin{array}{l}\text { Fourth phase: Themes } \\
\text { Tabulating }\end{array}$ & $\begin{array}{l}\text { Reviewed researchers' taken-for-granted assumptions. Developed, refined, } \\
\text { and rearranged themes to further distil key assumptions. Discussed and } \\
\text { reviewed analytical notes with other researchers to tabulate key themes with } \\
\text { related concepts }\end{array}$ \\
\hline
\end{tabular}

Conducting the analysis manually, rather than using assistive technology, revealed directors' latent themes, which is critical to addressing the research question on taken-for-granted assumptions (Clarke \& Braun, 2018; DeSantis \& Ugarriza, 2000). This manual approach distinguished values-in-use from espoused values, which can be difficult given directors' stories are "mediated via impression management, political action, morals, social codes, and cultural transcripts" (Sandberg, 2005, p. 56; Tracy, 2010). When combined, the multiple data sources employed contributed to the trustworthiness and credibility of this qualitative approach (Fusch, Fusch, \& Ness, 2018; Yin, 2014). 


\section{Findings}

Thematic content analysis produced 400 pages of interview data, which was triangulated with archival corporate reports and observational checklists. Eventually four key themes from the interview data set on assumptions (values-in-use) emerged, which differed from the key archival documents (espoused values) themes. Directors' assumptions were finance first, followed by risk, defensibility, and omission (see Table 2). The final theme, omission, is implicit because some CSR dimensions consistently sat outside directors' assumptions. In general, participant interview themes contradicted with espoused values in corporate reports, which prioritised customer centricity, integrity, trustworthiness, and professionalism. Of the six CSR dimensions most directors consider three to five of the dimensions in their day-today role. The economic dimension is considered first, followed by stakeholder, social, ethical, discretionary, and sustainability is last. The following findings are presented in an exploratory context where it is prudent to note the number of participants was 11 and snowballing was utilised, which may have influenced themes. 
Table 2.

Key themes from director assumptions

\begin{tabular}{|c|c|c|}
\hline $\begin{array}{l}\text { Key theme (from } \\
\text { assumptions) }\end{array}$ & Explanation & $\begin{array}{l}\text { Exemplary quote (pseudonym indicates } \\
\text { particular director) }\end{array}$ \\
\hline $\begin{array}{l}\text { Finance first: } \\
\text { primary reason } \\
\text { directors' } \\
\text { espoused } \\
\text { behaviour differs } \\
\text { from day-to-day } \\
\text { assumptions, their } \\
\text { values-in-use }\end{array}$ & $\begin{array}{l}\text { - Finance is prioritised first; it impacts } \\
\text { everything, finance expectations need } \\
\text { to be met } \\
\text { - Make as much money as you can } \\
\text { - Heaviness in managing other people's } \\
\text { money } \\
\text { - Shareholders profit demands } \\
\text { - Staff incentivisation is short-term and } \\
\text { intense } \\
\text { - Industry and customers expect short- } \\
\text { term profit, irrespective of commercial } \\
\text { or not-for-profit operation } \\
\text { Customers' poor financial literacy } \\
\text { equates to vulnerable customers }\end{array}$ & $\begin{array}{l}\text { - "Profit is all they [shareholders] care about" } \\
\text { (PQ) } \\
\text { "Our role is to make as much money as we } \\
\text { possibly can to distribute to shareholders" } \\
\text { (PQ) } \\
\text { "We work hard governing other people's } \\
\text { money; it's a big job; you are } \\
\text { professionally tested" (RS) } \\
\text { "Profit right now philosophy" (PQ) and } \\
\text { "Shareholders want a 5\% dividend every } \\
\text { year" (CD) } \\
\text { "Financial advisors make more money from } \\
\text { commission...they are more aggressive } \\
\text { than they should be" (EF) } \\
\text { "Industry gives accolades if you deliver in } \\
\text { short term" (RS) and "Low socio-economic } \\
\text { customers want immediate profit" (XY) } \\
\text { "Taking some risk off the table" is not } \\
\text { viewed favourably by customers in a } \\
\text { vulnerable position (RS) }\end{array}$ \\
\hline Risk & $\begin{array}{l}\text { - } \quad \text { Risk to reputation and cyber safety } \\
\text { - } \quad \text { Being too comfortable } \\
\text { - } \quad \text { Stonewalling on questioning } \\
\text { - } \quad \text { Low qualification level to enter } \\
\text { industry } \\
\text { - Misogyny in industry leads to abuse of } \\
\text { junior female staff }\end{array}$ & $\begin{array}{l}\text { - "We need more education on cyber risks" } \\
\text { - } \quad \text { "WF) } \\
\text { famlilyish" (PQ and LM) } \\
\text { - "More questions would be asked if there } \\
\text { wasn't so much pushback" (LM) } \\
\text { "I've struggled to get cowboys, bad apples, } \\
\text { out" (PQ) and "cowboys" bring industry } \\
\text { down (TV and RS) } \\
\text { "I would kill him if it was legal" (PQ) }\end{array}$ \\
\hline Defensibility & $\begin{array}{l}\text { Directors need to defend themselves: } \\
\text { legally, as well as to shareholders and } \\
\text { regulators } \\
\text { - } \quad \begin{array}{l}\text { Defence against paying for negative } \\
\text { externalities }\end{array} \\
\text { - Aggressiveness justified }\end{array}$ & $\begin{array}{l}\text { - Cannot invest in renewables because "The } \\
\text { returns are poor to the customer...but, we } \\
\text { don't want to be taxed out of existence" } \\
\text { (NO) } \\
\text { "Your morality is fine, just don't ask me to } \\
\text { pay for it" (TV) } \\
\text { "Pure bullying needed to get the job done" } \\
\text { (PQ) }\end{array}$ \\
\hline Omission & $\begin{array}{l}\text { - } \quad \text { Lack of consideration of environmental } \\
\text { sustainability and ESG } \\
\text { - Diversity }\end{array}$ & $\begin{array}{l}\text { - "We're not mining" (CD, NO, PQ, RS) and } \\
\text { "We have other people looking after ESG" } \\
\text { (XY) } \\
\text { "It's not something I think about" (NO and } \\
\text { TV) }\end{array}$ \\
\hline
\end{tabular}

The dominant finance first theme has some alignment with CSR economic dimension; this theme was inter-linked to the other three themes, regardless of commercial or NfP standing. Incentivisation for directors and staff to deliver profits in the short-term was a 
constant theme, which some directors acknowledged could lead to increased risk. Directors spoke of staff being under pressure to perform financial product sales roles, which incorporates two CSR dimensions: economic and stakeholder; this sentiment was expressed by EF as, "Financial advisors make more money from commission...they are more aggressive than they should be." Directors' staff, in financial advisory roles, have a fiduciary duty to customers who trust them to provide advice in their best interests (Lydenberg, 2014). Financial advisors who consider two dimensions of CSR may meet the values-in-use of the organisation, but fall short on community expectations (Hayne, 2019a). The nature of the special trusting fiduciary relationship advisors have with their customers requires all six dimensions be considered: economic, ethical, social, stakeholder, sustainability, and discretionary (Lydenberg, 2014; Sarkar \& Searcy, 2016).

In general, directors considers the sustainability dimension least. When questioned on this omission at the end of the interview directors spoke of a systematic short-term orientation they could not change. One director, $\mathrm{CD}$, expressed the pressure to deliver shortterm financial profit as, "shareholders want a 5\% dividend every year" [CD]. There was, however, one irregularity in the participant cohort. RS spoke of how their organisation was changing their incentive structures internally to promote a more long-term customer orientation. The introduction of the different structure had resulted in internal challenges, with RS stating, "It is a bloody big challenge, it's a cultural shift."

Directors' espoused values were often disconnected with interview assumption data. All directors were aware of a large gap between espoused values and day-to-day assumptions, with RS saying, "The gap is enormous, enormous! The financial services industry in particular is very good at talking about itself, for itself." When discussing this cultural gap most directors inserted a caveat: that is, while there is a large gap in most Australian organisations, the gap in their own was small. Contradictions between the 
interview data and archival documents were more pronounced with commercial participants. For example, participant CD continually prioritised shareholders stating, "Definitively shareholder first every time." CD's statement conflicted with their archival documents espousing customer centricity; this example highlights how short-term financial profit for the shareholders is the primary value-in-use, all the while using a cultural script of customer centricity in reports.

Managing risk was the second largest theme. Key risks identified were reputation, which is aligned to the ethical dimension; cyber safety, aligned to economic, ethical, and stakeholder dimensions; and the board feeling "too comfortable", the social dimension. PQ and LM explained the issue of being "too comfortable" relates to directors not wanting to lose face so they do not ask questions. Additionally, executive directors stonewalling, as a response to questions asked by non-executive directors, was consistently raised. "Bad apples" were another risk directors discussed. One type of a bad apple described was a "cowboy" with low qualification levels who is negligent in managing people's life savings. Another type of bad apple was men who use their high level of power within an organisation to abuse subordinate female staff. The risk of bad apples was not new. Indeed, participants spoke of trying to remove bad apples for years, yet the industry as a system has allowed those convicted of misconduct in one organisation to secure roles in another finance organisations.

Defensibility, that is, directors need to defend themselves legally or otherwise to shareholders, regulators, and other stakeholders, was the third key theme. One example of this was defending why they would not invest in certain renewable energies. Rationale for this defence was potential poor returns and a belief that investors do not want to subsidise other people's values, which was expressed as, "Your morality is fine, just don't ask me to pay for it" [TV]. While directors did not consider negative environmental sustainability externalities, they were cautious of avoiding investments generating a high tax rate or penalty 
due to environmental issues because "we don't want to be taxed out of existence" [NO]. Directors also defended aggressiveness in others and themselves, saying that at times "pure bullying" [PQ] was justified because it displayed a "commitment to getting the job done" [XY]. Throughout these defensive responses' participants' body language, or, tone of voice changed.

The final theme omission arose because the majority of directors did not discuss some dimensions of CSR, notably sustainability, as it related to the environment; it was not a consideration in their day-to-day work. At the end of the interview directors were explicitly asked about the environment or ESG. Many directors drew from the same cultural script, stating "We're not mining" [CD, NO, PQ, RS]; implying finance as morally superior to mining. Other approaches to sustainability complexities included delegating power to an investment subcommittee or giving sustainability issues to an ethics subcommittee. Across the range of environmental sustainability discussions, one director had a significantly different approach. EF stated that they incorporate environmental sustainability into their day-to-day tasks throughout the organisation. Examples corroborating these claims included office building design, buying carbon offsets, soft copies of board packs, and incentives for lending customers to choose products that protected or benefitted the environment. These examples cover all six CSR dimensions and support EF's espoused values in corporate reports and interview data assumptions.

While there were contradictions across the data sets, there was some corroboration. All three data sets corroborated on a conservative approach. That is, during the interviews directors stated their approach was "conservative", because they were dealing with other people's money; similarly, their corporate reports were written and displayed conservatively, as was the office set-up and director attire. Other areas of corroboration included external board meeting occurrences, staff volunteering, recycling paper, and reading regulatory 
requirements. While the findings indicated congruence in some areas, overall the key finding was incongruence between stated key espoused values of customer centricity (stakeholder CSR dimension) and their values-in-use: finance (economic CSR dimension). The following discussion explores this incongruence in more depth.

\section{Discussion}

The response to the research question that asked why there is a difference between what directors espouse in their corporate reports and CSR assumptions is captured in Table 3. Thematic content analysis revealed directors' primary value-in-use is finance first (short-term profitability). Directors' corporate reports primary espoused value was customers centricity. The value-in-use, finance first assumption, rather than customer first, comes from directors' fear of not meeting finance expectations which could result in board removal. Prioritising finance is not a significant surprise given the industry is finance. Sarkar and Searcy (2016) advised that, historically, finance (economic dimension) is the first consideration of CSR; similarly, Schein (2010) stated the director subculture prioritises finance and board considerations. What is surprising is the industry continues to state customers are first. The incongruent finance first assumption, while continuing to espouse customer centricity, could be a driving factor in the low levels of trust in the industry (Endelman, 2018; Wilson et al., 2019): only 20\% of Australians believe banks are ethical (Punt, 2018). 
Table 3:

Finance Directors prioritisation

\begin{tabular}{|c|c|c|c|}
\hline Research question & $\begin{array}{l}\text { Assumptions: values-in- } \\
\text { use (interviews) }\end{array}$ & $\begin{array}{l}\text { Espoused values } \\
\text { (reports) }\end{array}$ & $\begin{array}{l}\text { Artifacts (observation \& } \\
\text { other data) }\end{array}$ \\
\hline $\begin{array}{l}\text { Why is there a difference } \\
\text { in what finance directors } \\
\text { espouse in their report and } \\
\text { their day-to-day CSR } \\
\text { assumptions (values-in- } \\
\text { use)? }\end{array}$ & 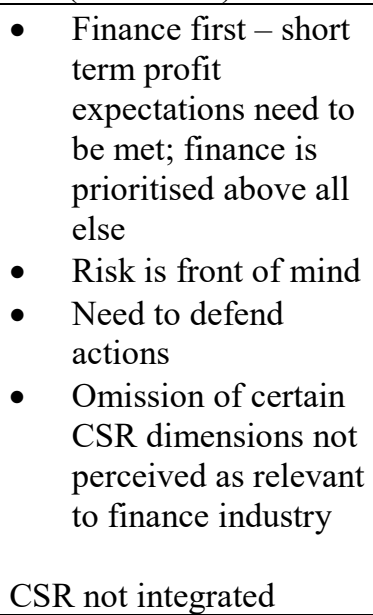 & $\begin{array}{l}\text { Customer centric- } \\
\text { customers are first } \\
\text { Integrity - guided } \\
\text { by organisation's } \\
\text { morals } \\
\text { Trustworthy - } \\
\text { organisation is } \\
\text { dependable } \\
\text { Professional - } \\
\text { organisation has } \\
\text { skilled staff } \\
\text { CSR integrated }\end{array}$ & $\begin{array}{l}\text { Conservative } \\
\text { approach to office } \\
\text { set up, attire, report } \\
\text { appearance, and } \\
\text { how discretionary } \\
\text { funding allocated } \\
\text { - } \\
\text { Read and discuss } \\
\text { regulation } \\
\text { requirements } \\
\text { - Board meeting } \\
\text { frequency } \\
\text { - Board reviews } \\
\text { - Recycle paper }\end{array}$ \\
\hline $\begin{array}{l}\text { CSR dimensions directors } \\
\text { consider (in priority order) }\end{array}$ & $\begin{array}{ll}\text { 1. } & \text { Economic } \\
\text { 2. } & \text { Stakeholder } \\
\text { 3. } & \begin{array}{l}\text { Social (gender } \\
\text { omitted in some }\end{array} \\
& \text { organisations) } \\
\text { 4. } & \text { Ethical } \\
\text { 5. } & \text { Discretionary } \\
& \text { (sometimes omitted) } \\
\text { 6. } & \begin{array}{l}\text { Sustainability } \\
\text { (environment often } \\
\text { omitted) }\end{array} \\
\end{array}$ & $\begin{array}{ll}\text { 1. } & \text { Stakeholders } \\
\text { 2. } & \text { Ethical } \\
\text { 3. } & \text { Economic } \\
\text { 4. } & \text { Social } \\
\text { 5. } & \text { Discretionary } \\
\text { 6. } & \text { Sustainability }\end{array}$ & \\
\hline
\end{tabular}

The contradiction of espoused values to values-in-use assumptions indicates

cognitive inconsistency: what is said and what is done is incongruent (Schein \& Schein, 2016). Fear of not meeting finance expectations is a greater driver than not meeting espoused customer values. A gap between espoused values and values-in-use, theorists advise, can be a breeding ground for defensive routines (Argyris, 2010; Schein \& Schein, 2016). Some defensive mechanisms appeared normalised in the interview data when directors rationalised a hands-off approach to sustainability because it could reduce short-term profit and generate a negative shareholder reaction in a highly competitive environment. Another manifestation of rationalising, as a defence mechanism, was directors justifying negative externalities because they needed to do the right thing by the shareholder and the regulator. Directors also rationalised their short-term incentivisation system to deliver aggressive monthly profit, because they were trapped in the industry system they could not change. To challenge and 
change dominant short-term assumptions to long-term sustainable assumptions would require a psychologically safe subculture (Lozano \& von Haartman, 2018). If attempts to enact changes resulted in failure, people would revert back to previous patterns, further perpetuating defensive routines (Argyris, 1990b; Schein \& Schein, 2016).

There was little evidence of strong internal drivers of CSR. Directors' core CSR driver was external: the regulator. Avoiding regulatory breaches and associated fines falls under directors' remit to manage risk (Gunningham, Kagan, \& Thornton, 2004; Lozano \& von Haartman, 2018). Environmental sustainability was perceived as a low risk to the industry to the point of being omitted from directors' day-to-day assumptions. Directors rationalisation of this positioning was "We're not mining" [CD, NO, PQ, RS]. The delegating of ESG or sustainability consideration to a specific department or a subcommittee confirms it is not yet an embedded assumption; but, rather, a defensive measure, or, an attempt to jumpstart interest in sustainability (Henriques \& Sadorsky, 1999; Russell \& McIntosh, 2011). If sustainability remains a concept that is talked about but not acted upon, it will be seen as a management fad; such fads foster defensive routines to the detriment of organisations (Argyris, 2010).

This study adds to Sarkar and Searcy's (2016) CSR study with the prioritisation of sustainability, when combined with the economic dimension, overall integration of CSR (CSR culture) improves. The benefit of prioritising sustainability with the economic, rather than prioritising the economic alone, was evident when comparing two commercial directors: RS and PQ. RS prioritised the economic dimension along with the long-term, sustainability dimension. This prioritisation of sustainability impacted the entire culture of the organisation because subordinate subcultures were expected to proactively manage customers' long-term financial wellbeing as a value-in-use. The dual economic-sustainability prioritisation stands in contrast to PQ's short-term economic profit assumption. PQ's subordinates were 
remunerated on short-term outcomes in an attempt to generate predicted shareholder profit. These (PQ's) subordinates were highly reactive to their personal remuneration. They also considered how far they could test the regulator boundary. Both directors (RS \& PQ) maintained they were doing the right thing; however, their CSR values-in-use resulted in different organisational outcomes. While a few CSR dimensions, such as economic and stakeholder, were considered in PQ's organisation, in RS's organisation all CSR dimensions were evident indicating a level of CSR embeddedness. Application of the six dimensions in RS's organisation included greater transparency between customers, staff, and society, which aligns with ethics; a climate where questioning is welcomed aligns with the social dimension; philanthropy was interwoven into the financial process, therefore discretionary activity; and there was active collaboration which incorporates the stakeholder dimension. This collaboration involved staff from different areas, such as law, ESG, tax, and investment, coming together to provide a comprehensive, multi-dimensional approach for the customer. Another indicator of RS's commitment to the CSR stakeholder dimension was frequent collaboration with external organisations (professionals and NfPs). If RS's organisation did not have particular expertise in an area that would add value to the customer they would actively collaborate with others. RS' organisation also hosts industry forums to discuss leadership issues and how collectively they can improve. Post Commission RS' organisation is thriving. Conversely PQ's organisation was found to have been involved in misconduct and is now being bought out.

Prioritising sustainability, with the economic dimension, was also beneficial for the integration of CSR in NfPs. Within the study, two NfP directors, EF and XY, prioritised the CSR economic dimension first, followed by the stakeholder dimension. EF also prioritised sustainability resulting in an innovative, more ethical approach to CSR across the organisation (further detail on EF's sustainability approach is discussed in the findings 
section p.19). Conversely, participants in XY's organisation did not prioritise sustainability and the approach appeared to be staid, business as usual. XY's organisation is now being taken over by a larger finance organisation. While EF and RS's examples of sustainability as a prioritised value-in-use is beneficial to integrating CSR culture and its long-term survival whether commercial or NfP, in this case study, most directors' values-in-use of the six dimensions were not embedded or integrated.

\section{Theoretical Implications}

The key contribution from this exploratory study is the prioritisation of sustainability, when coupled with the economic dimension, results in a better integration of all six CSR dimensions. Sustainability prioritisation was found to be a key to the embedding of CSR culture whether commercial or NfP. This insight adds to the study by Sarkar and Searcy (2016) in which they discuss the economic CSR dimension as prioritised. Salient findings of incongruence between directors' short-term finance first values-in-use, and their espoused values of customer centricity are captured in Table 3. Similarly, Table 2 captures thematic analysis to do with "why" some of this incongruence exists which is significant as it articulates the values-in-use (short-term financial gain) in the lead-up to the Commission on finance misconduct. More broadly, this paper provides an insight into the director black box complete with verbatim quotes, rather than solely drawing from espoused scripts. Culture and subculture within finance has been studied less than in other industries; yet, their impact is significant as they perform a "de-facto role as custodians of society's resources" (Herbohn, Gao, \& Clarkson, 2019, p. 155; Li, Griffin, Yue, \& Zhao, 2013; Sheedy, 2016). In short, this exploratory study presents a case for increased director field research to gain authentic, trustworthy insight on CSR culture. Other industries experiencing trust deficits may also benefit from investigation into their director subculture. 


\section{Practical Implications}

There are a number of practical implications from this exploratory study; however, further research is required given the small participant size. Potential implications include the need for directors' acknowledgement of the gap between their values-in-use and their espoused values within their own organisation. Increased awareness of the benefit of prioritising sustainability for the long-term survival of the organisation may incorporate adjusting incentive structures for subordinates. Creating a psychologically safe space on the board for directors to discuss "undiscussables" is also advised. This safe space could enable assumptions to be challenged so as to avoid deferring to defensive mechanisms that then set the tone for defensive routines throughout the organisation. Understanding the regulator, as the foremost driver of CSR, is another consideration. Here the regulator may wish to utilise its power to improve the industry's professionalism, reducing the number "cowboys" and providing increased safeguards to vulnerable customers. That said, achieving cultural change, particularly if it is through external drivers, will be a challenge. This sentiment was captured in PQ's statement: “I don't need outsiders telling me what my ethics should be." Large finance organisation's reluctance to re-learn and change behaviour, as per the Commission's 2019 recommendations, has been reported in the media (Cranston, 2019).

\section{Conclusion}

In this exploratory interpretive case study on Australian finance directors, new insights are offered into the culture of finance industry in the lead-up to the Commission. Directors' espoused CSR values in corporate reports stating customer centricity as their driver was found to be mismatched to their value-in-use of finance first (short-term profit assumption). Directors lived experience of the six dimensions of CSR was not integrated in most participants' large financial organisations. Rather, directors demonstrated a normalisation of incongruence between what was said and 
what was done. This incongruence provided fertile soil for defensive routines where "profit-now" assumptions were not questioned. There were, however, some small exceptions. Directors who prioritised the sustainability dimension of CSR as well as the economic, resulted in better integration of CSR. Post Commission, the organisations of directors who prioritised sustainability are thriving, while others who only prioritised the economic dimension (commercial organisation) or economic and stakeholder dimensions (NfP), have been bought out in some instances.

Thematic content analysis from director interviews, archival documents, and observation checklists revealed directors' assumptions differ from espoused values because of the pressure to meet short-term profit expectations. Other key director assumptions were managing risk, such as reputation, cyber safety, and low levels of professionalism. There was also evidence of defence routines, which included the need to rationalise sustainability not being considered as a day-to-day consideration and explaining profitability to shareholders.

A failure to meet short-term profit expectations, not manage risk, or offer seemingly indefensible rationale could result in board expulsion. Espoused values in reports prioritising customer centricity, integrity, trustworthiness, and professionalism differed from director day-to-day assumptions. Specific contributions into why there was director incongruence between espoused values and values-in-use in the lead-up to the Commission is new; however, the concept of what people say differing from what they do is not new (Argyris \& Schon, 1978; Schein $\&$ Schein, 2016; Searle, 1969). The subjectivist, interpretive investigation draws into question the trustworthiness of corporate reports claiming to have an integrated CSR culture. Limitations in this research include theories not covered such as institutional 
theory or stakeholder salience theory; participant size (while saturation of concepts were achieved, the study was not extensive); and other subculture voices such as the operator or middle management were not captured. These limitations now pose as opportunities for future investigation.

The CSR cultural approach brings new insight to an industry experiencing a trust deficit and calls for improved culture (Hayne, 2019a; Punt, 2018). Failure to adjust elements of director subculture may result in further erosion of trust, longterm financial detriment, dispiriting defensive routines, and organisations being bought out. In conclusion, improved sustainability assumptions for directors have the potential to integrate CSR as a value-in-use, reduce some financial risks, and positively impact the millions of customers they serve. 


\section{References}

Ali, H. Y., Danish, R. Q., \& Asrar-ul-Haq, M. (2019). How corporate social responsibility boosts firm financial performance: The mediating role of corporate image and customer satisfaction. Corporate Social Responsibility and Environmental Management, $0(0)$. doi:10.1002/csr.1781

Alvesson, M., Gabriel, Y., \& Paulsen, R. (2017). Return to meaning: A social science with something to say. Oxford, England: Oxford University Press.

Angen, M. J. (2000). Evaluating interpretive inquiry: Reviewing the validity debate and opening the dialogue. Qualitative Health Research, 10(3), 378-395.

Ardalan, K. (2016). On the role of paradigms in finance. Hampshire, England: Routledge.

Argyris, C. (1990a). The dilemma of implementing controls: the case of managerial accounting. In Readings in accounting for management control (pp. 669-680): Springer.

Argyris, C. (1990b). Overcoming organizational defenses. Boston, MA: Allyn and Bacon.

Argyris, C. (2010). Organizational traps: Leadership, culture, organizational design. Oxford, England: Oxford University Press.

Argyris, C., \& Schon, D. (1978). Organizational learning: A theory of action approach. Reading, MA Addision Wesley.

Ashkanasy, N. M., Humphrey, R. H., \& Huy, Q. N. (2017). Integrating emotions and affect in theories of management. Academy of Management Review, 42(2), 175-189.

Asif, M., Searcy, C., Zutshi, A., \& Fisscher, O. A. (2013). An integrated management systems approach to corporate social responsibility. Journal of Cleaner Production, $56,7-17$. 
Australian Council on Superannuation Investors. (2017). Corporate Sustainability Reporting in Australia: 2017. Retrieved from Melbourne, Australia:

https://www.acsi.org.au/sustainability-reporting.html

Australian Government Department of Treasury. (1997). Final Report of the Financial System Inquiry. Retrieved from Canberra, Australia:

https://www.aph.gov.au/About Parliament/Parliamentary Departments/Parliamentary _Library/pubs/rp/RP9697/97rp16

Australian Government Department of Treasury. (2016). Backing Australian FinTech. Canberra, Australia Retrieved from https://fintech.treasury.gov.au/files/2016/03/Fintech-March-2016-v3.pdf

Australian Prudential Regulation Authority. (2016). Information paper: Risk culture. Sydney, Australia: APRA Retrieved from https:/www.apra.gov.au/sites/default/files/161018information-paper-risk-culture1.pdf

Australian Securities \& Investment Comission. (2013). Regulatory Guide 121: Doing financial services business in Austalia. In (pp. 1-53). Australian Capital Territory, Australia: ASIC.

Baden, D., \& Harwood, I. A. (2013). Terminology matters: A critical exploration of corporate social responsibility terms. Journal of Business Ethics, 116(3), 615-627.

Barnett, M. L. (2016). The Business Case for Corporate Social Responsibility. Business \& Society, 1-24. doi:10.1177/0007650316660044

Beck, C., Frost, G., \& Jones, S. (2018). CSR disclosure and financial performance revisited: A cross-country analysis. Australian Journal of Management, 43(4), 517-537.

Bencherki, N., Basque, J., \& Rouleau, L. (2019). A Sensemaking Perspective on Open Strategy. In D. Seidl, R. Whittington, \& G. Von Krough (Eds.), The Cambridge Handbook of Open Strategy. Cambridge, UK: Cambridge University Press. 
Biktimirov, E. N., \& Cyr, D. (2013). Using Inside Job to teach business ethics. Journal of Business Ethics, 117(1), 209-219.

Braun, V., \& Clarke, V. (2006). Using thematic analysis in psychology. Qualitative Research in Psychology, 3(2), 77-101.

Buertey, S., Sun, E.-J., Lee, J. S., \& Hwang, J. Corporate social responsibility and earnings management: The moderating effect of corporate governance mechanisms. Corporate Social Responsibility and Environmental Management, 0(0). doi:10.1002/csr.1803

Busch, T., \& Friede, G. (2018). The Robustness of the Corporate Social and Financial Performance Relation: A Second-Order Meta-Analysis. Corporate Social Responsibility and Environmental Management, 25(4), 583-608. doi:10.1002/csr.1480

Busch, T., Hamprecht, J., \& Waddock, S. (2018). Value(s) for Whom? Creating Value(s) for Stakeholders. Organization \& Environment, 31(3), 210-222. doi:10.1177/1086026618793962

Campbell, K. (1981). The Campbell Committe Report [Australian Financial Systems Inquiry]. Retrieved from Canberra, Australia: http://fsi.gov.au/publications/

Carroll, A. B., \& Shabana, K. M. (2010). The business case for corporate social responsibility: A review of concepts, research and practice. International Journal of Management Reviews, 12(1), 85-105.

Chabrak, N., Craig, R., \& Daidj, N. (2016). Financialization and the employee suicide crisis at France Telecom. Journal of Business Ethics, 139(3), 501-515.

Chapple, W., \& Moon, J. (2007). CSR agendas for Asia. Corporate Social Responsibility and Environmental Management, 14(4), 183-188.

Clarke, V., \& Braun, V. (2018). Using thematic analysis in counselling and psychotherapy research: A critical reflection. Counselling and Psychotherapy Research, 18(2), 107110. doi:10.1002/capr.12165 
Commonwealth Bank. (2018). Annual Report 2018, Becoming a simpler, better bank.

Retrieved from Sydney, Australia:

https://www.commbank.com.au/content/dam/commbank/about-

us/shareholders/pdfs/results/fy18/cba-annual-report-2018.pdf

Commonwealth of Australia. (2001). Corporations Act 2001. Canberra, Australia: Australian Government Retrieved from

http://classic.austlii.edu.au/au/legis/cth/consol act/ca2001172/s180.html

Cranston, M. (2019). Treasurer slams ANZ as CBA, NAB cut in full. Australian Financial Review. Retrieved from https://www.afr.com/news/economy/monetary-policy/rbacuts-interest-rates-to-1-25-per-cent-20190604-p51u86

Cucari, N., Esposito De Falco, S., \& Orlando, B. (2018). Diversity of board of directors and environmental social governance: Evidence from Italian listed companies. Corporate Social Responsibility and Environmental Management, 25(3), 250-266.

Cummings, T. G., \& Worley, C. G. (2015). Organization development and change (10 ed.). Stamford, CT: Cengage Learning.

Cunliffe, A. L. (2003). Reflexive inquiry in organizational research: Questions and possibilities. Human Relations, 56(8), 983-1003.

DeSantis, L., \& Ugarriza, D. N. (2000). The concept of theme as used in qualitative nursing research. Western Journal of Nursing Research, 22(3), 351-372.

Dick, R. (1990). Convergent interviewing. Chapel Hill, Australia: Interchange.

Ducassy, I. (2013). Does corporate social responsibility pay off in times of crisis? An alternate perspective on the relationship between financial and corporate social performance. Corporate Social Responsibility and Environmental Management, 20(3), 157-167. 
Edmondson, A. (1999). Psychological safety and learning behavior in work teams. Administrative Science Quarterly, 44(2), 350-383.

Endelman. (2018). Australia: Trust in Tumult. Retrieved from https://www.edelman.com/post/australia-trust-in-tumult

Eweje, G. (2011). A shift in corporate practice? Facilitating sustainability strategy in companies. Corporate Social Responsibility and Environmental Management, 18(3), 125-136.

Fligstein, N. (1990). The transformation of corporate control. Cambridge, MA: Harvard University Press.

Furlotti, K., Mazza, T., Tibiletti, V., \& Triani, S. (2018). Women in top positions on boards of directors: Gender policies disclosed in Italian sustainability reporting. Corporate Social Responsibility and Environmental Management. doi:10.1002/csr.1657

Fusch, P., Fusch, G. E., \& Ness, L. R. (2018). Denzin's paradigm shift: Revisiting triangulation in qualitative research. Journal of Social Change, 10(1), 19-32.

Galbreath, J. (2011). Are there gender-related influences on corporate sustainability? A study of women on boards of directors. Journal of Management \& Organization, 17(1), 1738.

Gunningham, N., Kagan, R. A., \& Thornton, D. (2004). Social license and environmental protection: why businesses go beyond compliance. Law \& Social Inquiry, 29(2), 307341.

Hahn, T., Figge, F., Pinkse, J., \& Preuss, L. (2018). A Paradox Perspective on Corporate Sustainability: Descriptive, Instrumental, and Normative Aspects. Journal of Business Ethics, 148(2), 235-248. doi:10.1007/s10551-017-3587-2 
Hahn, T., Preuss, L., Pinkse, J., \& Figge, F. (2014). Cognitive frames in corporate sustainability: Managerial sensemaking with paradoxical and business case frames. Academy of Management Review, 39(4), 463-487.

Hayne, K. M. (2018). Interim Report: Royal Comission into Misconduct in the Banking, Superannuation and Financial Services Industry, Volume 1. Retrieved from Canberra, Australia: https://financialservices.royalcommission.gov.au/Documents/interimreport/interim-report-volume-1.pdf

Hayne, K. M. (2019a). Final Report: Royal Commission into Misconduct in the Banking, Superannuation and Financial Services Industry, Volume 1. Retrieved from Canberra, Australia: https://financialservices.royalcommission.gov.au/Pages/reports.aspx\#final

Hayne, K. M. (2019b). Final Report: Royal Commission into Misconduct in the Banking, Superannuation and Financial Services Industry, Volume 2: Case Studies. Retrieved from Canberra, Australia:

https://financialservices.royalcommission.gov.au/Pages/reports.aspx\#final

Hayne, K. M., Cosgrove, P., Orr, R., Hodge, M., Dinelli, A., Dias, E., \& Costello, M. (2019). Royal Commission into Misconduct in the Banking, Superannuation and Financial Services Industry. Retrieved from https://financialservices.royalcommission.gov.au/Pages/default.aspx

Helms Mills, J. C., \& Mills, A. J. (2017). Rules, Sensemaking, Formative Contexts, and Discourse in the Gendering of Organizational Culture. In L. Booysen, R. Bendl, \& J. Pringle (Eds.), Handbook of Research Methods in Divresity Management, Equality and Inclusion (pp. 49-69): Emerald Publishing Limited.

Henriques, I., \& Sadorsky, P. (1999). The relationship between environmental commitment and managerial perceptions of stakeholder importance. Academy of Management Journal, 42(1), 87-99. 
Herbohn, K., Gao, R., \& Clarkson, P. (2019). Evidence on Whether Banks Consider Carbon Risk in Their Lending Decisions. Journal of Business Ethics, 158(1), 155-175. doi:10.1007/s10551-017-3711-3

Higgins, C., Milne, M. J., \& Van Gramberg, B. (2015). The uptake of sustainability reporting in Australia. Journal of Business Ethics, 129(2), 445-468.

Hockerts, K. (2015). A cognitive perspective on the business case for corporate sustainability. Business Strategy and the Environment, 24(2), 102-122.

Howard-Grenville, J. (2006). Inside the "black box" how organizational culture and subcultures inform interpretations and actions on environmental issues. Organization \& Environment, 19(1), 46-73.

Jahdi, K. S., \& Acikdilli, G. (2009). Marketing Communications and Corporate Social Responsibility (CSR): Marriage of Convenience or Shotgun Wedding? Journal of Business Ethics, 88(1), 103-113. doi:10.1007/s10551-009-0113-1

Jain, A., Keneley, M., \& Thomson, D. (2015). Voluntary CSR disclosure works! Evidence from Asia-Pacific banks. Social Responsibility Journal, 11(1), 2-18. doi:10.1108/SRJ10-2012-0136

Jizi, M. (2017). The influence of board composition on sustainable development disclosure. Business Strategy and the Environment, 26(5), 640-655.

Johnson, P., \& Duberley, J. (2000). Understanding Management Research. London, UK: Sage Publications.

Kim, R. C., \& Moon, J. (2015). Dynamics of corporate social responsibility in Asia: Knowledge and norms. Asian Business \& Management, 14(5), 349-382.

Kok, A. M., de Bakker, F. G. A., \& Groenewegen, P. (2017). Sustainability Struggles: Conflicting Cultures and Incompatible Logics. Business \& Society, 1-37. doi:10.1177/0007650317703644 
Kolk, A. (2016). The social responsibility of international business: From ethics and the environment to CSR and sustainable development. Journal of World Business, 51(1), 23-34.

Kolko, J. (2010). Abductive thinking and sensemaking: The drivers of design synthesis. Design Issues, 26(1), 15-28.

Kurucz, E. C., Colbert, B. A., \& Wheeler, D. (2008). The business case for corporate social responsibility. In A. Crane, A. McWilliams, D. Matten, J. Moon, \& D. Siegel (Eds.), The Oxford handbook of corporate social responsibility (pp. 84-112). New York, NY: Oxford University Press.

Laker, J., Broadbent, J., \& Samuel, G. (2018). Prudential Inquiry into the Commonwealth Bank of Australia. Retrieved from Sydney, Australia: https://www.apra.gov.au/sites/default/files/CBA-Prudential-Inquiry FinalReport 30042018.pdf

Lane, A. B., \& Devin, B. (2018). Operationalizing stakeholder engagement in CSR: A process approach. Corporate Social Responsibility and Environmental Management, 25(3), 267-280.

Leblanc, R., \& Schwartz, M. S. (2007). The black box of board process: Gaining access to a difficult subject. Corporate Governance: An International Review, 15(5), 843-851. Li, K., Griffin, D., Yue, H., \& Zhao, L. (2013). How does culture influence corporate risktaking? Journal of Corporate Finance, 23, 1-22.

Lichterman, P. (2017). Interpretive reflexivity in ethnography. Ethnography, 18(1), 35-45. Lozano, R., \& von Haartman, R. (2018). Reinforcing the Holistic Perspective of Sustainability: Analysis of the Importance of Sustainability Drivers in Organizations. Corporate Social Responsibility and Environmental Management, 25(4), 508-522. doi:10.1002/csr.1475 
Lydenberg, S. (2014). Reason, rationality, and fiduciary duty. Journal of Business Ethics, $119(3), 365-380$.

Manning, B., Braam, G., \& Reimsbach, D. (2019). Corporate governance and sustainable business conduct —Effects of board monitoring effectiveness and stakeholder engagement on corporate sustainability performance and disclosure choices. Corporate Social Responsibility and Environmental Management, 26(2), 351-366. doi:10.1002/csr.1687

Migliore, L.-A., \& DeClouette, A. (2011). Perceptions of Trust in the Boardroom: A Coneptual Model. Journal of Leadership \& Organizational Studies, 18(3), 320-333. doi:10.1177/1548051811 404893

Morgan, G. (1988). Accounting as reality construction: towards a new epistemology for accounting practice. Accounting, Organizations and Society, 13(5), 477-485.

Murray, D. (2014). Financial System Inquiry Final Report. Retrieved from Canberra, Australia: http://fsi.gov.au/publications/final-report/

National Australia Bank. (2018). Sustainability Report 2018. Retrieved from Melbourne, Australia:

https://www.nab.com.au/content/dam/nabrwd/documents/reports/corporate/2018$\underline{\text { sustainability-report.pdf }}$

Ness, L. R. (2015). Are we there yet? Data saturation in qualitative research. 1408-1416.

Oeij, P. R., Dhondt, S., Gaspersz, J. B., \& Vroome, E. M. D. (2016). Can teams benefit from using a mindful infrastructure when defensive behaviour threatens complex innovation projects? International Journal of Project Organisation and Management, $8(3), 241-258$.

Oldham, M., \& Kleiner, B. (1990). Understanding the nature and use of defence mechanisms in organisational life. Journal of Managerial Psychology, 5(5), 1-4. 
Ortiz-de-Mandojana, N., Aguilera-Caracuel, J., \& Morales-Raya, M. (2016). Corporate Governance and Environmental Sustainability: The Moderating Role of the National Institutional Context. Corporate Social Responsibility and Environmental Management, 23(3), 150-164. doi:10.1002/csr.1367

Palpacuer, F., Seignour, A., \& Vercher, C. (2011). Financialization, globalization and the management of skilled employees: Towards a market-based HRM model in large corporations in France. British Journal of Industrial Relations, 49(3), 560-582.

Pellegrini, C., Annunziata, E., Rizzi, F., \& Frey, M. (2019). The role of networks and sustainable intrapreneurship as interactive drivers catalyzing the adoption of sustainable innovation. Corporate Social Responsibility and Environmental Management, 0, 1-23. doi:10.1002/csr.1784

Pope, R. (2019). Organizational Silence in the NHS:'Hear no, See no, Speak no'. Journal of Change Management, 19(1), 45-66.

Porter, M., \& Kramer, M. (2011). The big idea: Creating shared value. Harvard Business Review, 62-77. Retrieved from https://hbr.org/2011/01/the-big-idea-creating-sharedvalue

Punt, W. (2018). Deloitte Trust Index - Banking 2018: The way forward to rebuild reputation and trust. Retrieved from Sydney, Australia: https://www2.deloitte.com/au/en/pages/financial-services/articles/deloitte-trust-indexbanking-survey.html

Roddan, M. (2019). The people vs the banks. Melbourne, Australia: Melbourne University Press.

Russell, S. V., \& McIntosh, M. (2011). Changing organizational culture for sustainability. In N. M. Ashkanasy, C. P. M. Wilderom, \& M. F. Oeterson (Eds.), The Handbook of 
Organizational Culture and Climate (pp. 393-411). Thousand Oaks, CA: Sage Publications.

Sackmann, S. A., \& Phillips, M. E. (2004). Contextual influences on culture research: Shifting assumptions for new workplace realities. International Journal of Cross Cultural Management, 4(3), 370-390.

Saldaña, J. (2015). The coding manual for qualitative researchers. London, UK: Sage Publications.

Salzmann, O., Ionescu-somers, A., \& Steger, U. (2005). The Business Case for Corporate Sustainability. European Management Journal, 23(1), 27-36. doi:10.1016/j.emj.2004.12.007

Sandberg, J. (2005). How do we justify knowledge produced within interpretive approaches? Organizational Research Methods, 8(1), 41-68.

Sarkar, S., \& Searcy, C. (2016). Zeitgeist or chameleon? A quantitative analysis of CSR definitions. Journal of Cleaner Production, 135, 1423-1435.

Schein, E. H. (1985). Organizational culture and leadership: a dynamic view. San Francisco: CA: Jossey-Bass.

Schein, E. H. (1990). Organizational culture. Sloan School of Management, MIT, 45(2), 1-58.

Schein, E. H. (2010). Organizational culture and leadership (Vol. 2). San Francisco, CA: John Wiley \& Sons.

Schein, E. H., \& Schein, P. (2016). Organizational Culture and Leadership (5th ed.). San Francisco: CA: Jossey-Bass.

Schreck, P., \& Raithel, S. (2018). Corporate social performance, firm size, and organizational visibility: distinct and joint effects on voluntary sustainability reporting. Business \& Society, 57(4), 742-778. 
Searle, J. R. (1969). Speech acts: An essay in the philosophy of language. Cambridge, England: Cambridge University Press.

Setó-Pamies, D. (2015). The relationship between women directors and corporate social responsibility. Corporate Social Responsibility and Environmental Management, $22(6), 334-345$.

Sheedy, E. (2016). Risk culture in Australian banks: Does size matter? The Australasian Journey of Applied Finance, 4-10.

Sheedy, E., \& Griffin, B. (2018). Risk governance, structures, culture, and behavior: A view from the inside. Corporate Governance: An International Review, 26(1), 4-22. doi:10.1111/corg.12200

Sheedy, E., Griffin, B., \& Barbour, J. P. (2017). A framework and measure for examining risk climate in financial institutions. Journal of Business and Psychology, 32(1), 101116.

Stewart, H., \& Gapp, R. (2014). Achieving effective sustainable management: A smallmedium enterprise case study. Corporate Social Responsibility and Environmental Management, 21(1), 52-64.

Stout, L. A. (2012). The shareholder value myth: How putting shareholders first harms investors, corporations, and the public. San Francisco, MA: Berrett-Koehler Publishers.

Sugita, M., \& Takahashi, T. (2015). Influence of corporate culture on environmental management performance: An empirical study of japanese firms. Corporate Social Responsibility and Environmental Management, 22(3), 182-192.

Terjesen, S., \& Sealy, R. (2016). Board gender quotas: Exploring ethical tensions from a multi-theoretical perspective. Business Ethics Quarterly, 26(1), 23-65. 
Tracy, S. J. (2010). Qualitative Quality: Eight “Big-Tent” Criteria for Excellent Qualitative Research. Qualitative Inquiry, 16(10), 837-851. doi:10.1177/1077800410383121

Ulysses, C. (2017). Sustainability and social impact. Retrieved from http://aicd.companydirectors.com.au/membership/company-director-magazine/2017$\underline{\text { back-editions/february/sustainability-and-social-impact }}$

Uribe-Bohorquez, M. V., Martínez-Ferrero, J., \& García-Sánchez, I.-M. (2018). Women on boards and efficiency in a business-orientated environment. Corporate Social Responsibility and Environmental Management, 1-15. doi:10.1002/csr.1659

Van Manen, M. (1997). From meaning to method. Qualitative Health Research, 7(3), 345369.

Vitolla, F., Rubino, M., \& Garzoni, A. (2017). The integration of CSR into strategic management: a dynamic approach based on social management philosophy. Corporate Governance: The International Journal of Business in Society, 17(1), 89116.

Weick, K. E. (1987). Organizational culture as a source of high reliability. California Management Review, 29(2), 112-127.

Wiengarten, F., Lo, C. K., \& Lam, J. Y. (2017). How does sustainability leadership affect firm performance? The choices associated with appointing a chief officer of corporate social responsibility. Journal of Business Ethics, 140(3), 477-493.

Wilson, S., Pallant, J., \& Bednall, T. C. (2019). Australian Leadership Index. Retrieved from Melbourne, Australia: https://www.australianleadershipindexblog.org/reportsblog/one-third-of-australians-think-banks-do-nothing-for-the-greater-public-good Yin, R. K. (2014). Case study research design and methods (5 ed.). Thousand Oaks, CA: Sage Publications. 
Yin, R. K. (2018). Case Study Research and Applications Designs and Methods (6th ed.). Thousand Oaks, CA: Sage Publications. 